\title{
Application of Multi-Criteria Analysis of Determining Sea Port Development Models in the Spatial Concept of a Town, Based on the Example of the Town of Rovinj
}

\author{
Mladen JARDAS, Donald SCHIOZZI, Željko SMOJVER
}

\begin{abstract}
A significant problem in port and port area development is the awareness that port development plans for county and local ports brought by port authorities in the capacity of a body managing the port and its port area, are often not covered by town and county physical planning solutions, and vice versa. The above said indicates that relevant parties in port area planning (port management and towns/countries) are not always active participants in the procedure of planning the ports and port areas in physical planning documents. County spatial plans do not pay necessary attention to the role, significance and development of the ports of county and local relevance. Drafting the spatial plans related to the ports of county and local relevance demands high level of expertise and multidisciplinary approach, as well as knowledge on the problem of physical planning, port operation and marine and coastal biology, maritime traffic technology and maritime environment protection. The purpose and the goal of this paper is to find the optimum model and measures for developing county and local ports in relation to the complementarity of spatial concept of the port and the town. For the purpose of defining and setting up the model, we used the most important indicators and measures that influence the level of physical planning of the port and the town. The example of Town of Rovinj will serve for checking and proving efficiency of the set-up model.
\end{abstract}

Keywords: multi-criteria analysis; port area; port development; port planning; urban planning

\section{INTRODUCTION}

In the Republic of Croatia, not all relevant factors influencing development of a town and port as a joint system are taken into consideration in practice. That is the result of viewing the port and the town as two separate units. A significant problem in county and local port development is that the plans for developing county and local ports, brought by port authorities acting in the capacity of a body managing the port and the port area, are usually not covered by physical planning solutions of the town and the county. Likewise, port authorities are introduced into the solutions of the port area, which have been planned by towns and counties, but only through the opinion of a relevant authority for implementation of the document, and by that time it is already too late to make any significant changes. It follows from the above said that the entities mentioned above are not active participants in the procedure of making plans about the ports and the pertaining port areas in the urban planning documents. The result of such a situation are port areas not based on the port authorities' development plans, and they usually fail to be satisfactory, either by the structure of the represented port activities or the capacity thereof, and especially by the surface area and shape of the port area. Sea port development is planned on a whim, with no theoretic or scientific support. Such plans do not apply all relevant elements influencing port development, and urban development of the area where the port is located. The said problem is especially reflected in the functioning of the entire port system and spatial development, which has a negative impact on the development of the entire economy. For the needs of the research, we used available documentation and bibliography, as well as electronic sources and data from various physical plans.

This paper is based on the hypothesis that ports may be planned and incorporated into the spatial concept of a town as a physical and functional unit, and in that manner increase their mutual development. Furthermore, it was necessary for the research to collect input data representing the basis for drafting the model. The data were collected by method of surveys and interviews. The surveys and interviews were performed on experts from various areas of scientific research or professional competencies (urban and spatial planners, heads of port authorities, heads of physical planning management departments, etc.) on inhabitants or occasional inhabitants of the town of Rovinj, tourists, i.e. occasional tourists visiting the town of Rovinj via organised excursions, cruiser guests and other tourists who are direct or indirect users of port services, such as boaters, businessmen, passenger carriers, shipping companies, etc.

The data obtained were statistically processed and a model was made, using multi-criteria analysis of data by means of software program PROMETHEE.

\section{REVIEW OF PREVIOUS RESEARCH}

Based on the collected and studied bibliographic units, it is clear that the recommended topic has not been addressed in the relevant manner. The said conclusion is confirmed by a small number of scientific and expert papers from the area.

Namely, there is a significant amount of scientific and expert papers on physical planning of ports and towns, however, there are not many papers on complementarity of the two systems, and papers on creating the same are very rare or non-existent. There is a larger number of papers on managing sea ports, i.e. on port authorities managing the ports, and out of the scientific papers with that topic, the ones standing out are written by Jugović, A. and Kesić, B. Even though the said authors have written numerous papers on sea port management, only one of them, written by Jugović, A. entitled: "Međuveza grada i pomorskoputničke luke u RH osnovni čimbenik njihovog uspješnog razvoja" [1], published in a scientific magazine Tourism and Hospitality Management in 2007, addresses in certain points the recommended topic of the doctoral thesis. The situation is similar when analysing expert literature, which still has not sufficiently recognized the need for researching the manner and models of planning development of ports and their surroundings as a single 
unit. The only expect paper standing out is the study written by a group of authors lead by Jugović, A. and Zec, D.: "Osnovne smjernice za planiranje luka otvorenih za javni promet županijskog značaja na području Primorskogoranske županije" from 2015, written for the needs of the Institute for Physical Planning of Primorje-Gorski Kotar County. In the said paper, the authors and their associates are trying to recommend appropriate solutions for resolving the differences of the presented problems, i.e. the problems concerning plans for development of the island of Krk and sea port development by applying scientific and practical experience on the example of a port authority (PA Krk). Concerning international papers, the paper that should be mentioned is the one by Pavia, R. and Di Venosa, M.: "Waterfront: dal conflitto all'integrazione: from conflict to integration" [2], which provides a detailed analysis of all conflicts occurring when urbanising the "Waterfront" of coastal towns and significant ports in the Mediterranean. Kortit, K., Macharis, C., and Nijkamp, P. in their article "A Multi-actor Multi-criteria analysis of the performance of global cities" [3] describe the performed research of the participants and the properties of urban centres (towns). Furthermore, the studies on port development are represented in papers written by Patrick, M., especially in the book "City, Capital and Water" [4] and the study by Gordon, D. on management and financing changes in the series of main urban locations on European and North American coasts (1996, 1997 a, 1997 b). It is interesting to note that the said studies are based on political science and have a tendency to maintain comparative approach appreciated by geographers, but there is a routine lack of the approach of such a study which is preferred elsewhere. Meyer $\mathrm{H}$. pointed out recently through a series of case studies ("City and Port: Urban Planning as a Cultural Venture in London, Barcelona, New York, and Rotterdam: Changing Relations between Public Urban Space and Large-Scale Infrastructure" [5]) that there are cultural dimensions included in planning port towns. There are various international organisations (CICA, AIVP, WAVE and other) providing valuable and complementary range of information and ideas. None is, of course, completely limited within artificial borders of any academic discipline, therefore, in their different manners, they are all trying to welcome a large diversity of points of view and expertise. As the phenomenon of port development and expansion spreads, in the geographical sense, it also attracts the attention of politics, spatial planners, ecologists, architects and engineers, as is described in the book written by White, K. N., et al.: "Urban Waterside Regeneration: Problems and Prospects" [6] and partly in the book: "The City Builders: Property, Politics, and Planning in London and New York", written by Fainstein, S. S. [7] The analysis of the available literature indicates the non-existence of any papers referring to the methodology of evaluating the model of developing county and local ports regarding the spatial concept of a town, as well as the non-existence of evaluation criteria or indicators. Even though there are papers on applying multi-criteria decision-making and optimisation, such papers have not been applied in the area of physical planning of port areas. The only scientific paper that definitely served as basis for preparing the methodology for evaluating projects of public-private partnership in sea ports is the paper written by Joerin, F., Theriault, M., Musy, A. "Using GIS and outranking multicriteria analysis for land-use suitability assessment" [8] published in IJGIS - International Journal of Geographical Information Science, (15 (2001), 2, pg. 153174) and Kovačić, M. "Selecting the location of a nautical tourism port by applying PROMETHEE and GAIA methods case study - Croatian northern Adriatic" [9], published in the magazine Promet - Traffic \& Transportation, (22 (2010), 5, pp. 341-351).

The paper indicated the application of the contemporary decision-making method by "multi-criteria analysis" in the field of physical planning. All of the above said proves justification of a scientific research concerning physical planning of the port area as a constituent part of the town and shows that this research shall help understand the implementation of the suggested models, improving, therefore, physical planning of a port area as a constituent part of the town.

\section{POSSIBILITY OF APPLYING MULTI-CRITERIA ANALYSIS ON COUNTY AND LOCAL PORTS DEVELOPMENT IN RELATION TO THE SPATIAL CONCEPT OF THE TOWN}

Appling multi-criteria decision-making (optimisation) in planning implies a systematic analysis of the problem. The systematic analysis, as a rational procedure in decision-making based on systematic and efficient organization and analysing available information, may be used to analyse and resolve various complex problems. It consists of the following elements, i.e. steps detecting the problem and orientation, defining the problem (goals, criteria, measures, borders, and work plan), determining and studying the status of the problem, generating scenarios (types) and selecting the most favourable scenario (type), forming and implementing the solution and improving the problem-solving procedure [10].

The task of multi-criteria decision-making (optimisation) is to select the best scenario (type, solution) from several possible scenarios in the sense of adopting a criterion. The criterion defines quality and presents a measure for comparison when selecting the best scenario. The criterion is expressed by a criteria function (or targetoriented function) which, in order to attain the best scenario (type, solution) must achieve the global extreme, taking into consideration limits representing the possibility of achieving the goal. Since the said procedure is minimising or maximising the given goal (criteria function) the term multi-criteria optimisation is used as well [11]. When defining the model, taking into consideration several criteria, it leads to multi-criteria optimisation, i.e. multicriteria decision-making. Decision-making, especially the multi-criteria one, is a complex process of reaching the solution. The general properties of each multi-criteria problem, unlike the singe-criteria one, are several decisionmaking criteria (objective function, criteria function), selection of several scenarios (types, solution) and selection process of one final scenario, i.e. one final solution [12]. One of the general preconditions for applying the multi-criteria decision-making process is to determine the combinations of selected indicators and their weighting factors. Changing thereof may show their 
influence on determining the model (scenario) development. By defining preferences, i.e. weighting factor, the wishes and intentions of the decision-maker are taken into consideration, resulting in the so-called preferred optimal solutions [13]. Since there are no identical opinions, measures or parameters, either in practice or in scientific literature, as to which indicators are crucial for defining the models of county and local port development in relation to the spatial concept of a town, it is difficult to form a priority list of individual indicators, i.e. to determine which indicators are important, which are of medium importance, and which are less important, etc. Sometimes, individual indicators gain and other lose importance and influence. There are even influences that appear positive in some periods, and in different circumstances or environment have a negative effect on the development of county and local ports concerning the spatial concept of a town [14]. Taking into consideration the above said, it should be pointed out that the weighting factors of the indicators refer to the conclusions obtained by research and that, due to the restricted scope of the research, not all possible combinations of the weighting factors of indicators (sub-indicators) have been analysed, but only a few of the combinations, although multi-criteria programming, using Visual PROMETHEE program, offers the option of ranking scenarios pursuant to various or all possible combinations of the indicator weighing factors [15].

\section{SCENARIO OF COUNTY AND LOCAL PORTS DEVELOPMENT IN RELATION TO THE SPATIAL CONCEPT OF THE PORT AND THE TOWN OF ROVINJ}

The multi-criteria analysis consists of identifying and sorting possible alternative solutions to the problem. Such alternatives - scenarios - models may be in different shapes, depending on the problem situation. They can include technological solutions of possible future scenarios along with the basic scenario, various political measures, longterm strategic options and similar [16]. In order to be able to use this methodology and analysis, it is important to have at least two possible alternatives - models - scenarios. Otherwise, this methodology cannot be applied. Taking into consideration international experiences, field research and legal provisions defining development of county and local ports in relation to the spatial concept of the town, and based on defined urban measures [17], four basic scenarios may be set up, Port serving the town and the inhabitants, Port serving tradition and cultural heritage, Port serving tourism and public coastal occasional and line transport of passengers and Port serving fisheries and industry.

Port serving the town and the inhabitants. The scenario of the port serving the town and the inhabitants represents the port as the urban centre, i.e. as a district fitting into the surrounding fibre of the town. The function of the port is stationary, i.e. it focuses on public utility berths, fishery berths and sports berths, while the capacity of nautical berths is decreased, as well as the length of operative pier for loading and unloading of passengers in coastal occasional and line traffic.

Port serving tradition and cultural heritage. A port as an urban centre, i.e. a port as a cultural and historic heritage of the town, refers to the development direction and the functional role of the port viewed through the need to preserve the way of life of the local population in close relation to the port. A port is the urban centre of the town and one of the key points of social life, both in the appearance and functional integrity of the town, and in the sense of a wider social context, namely, how the local population lives and works, from cultural, recreational, sports and similar activities, through religious values to the values of general society, linked to the role and the significance that the port has for a town.

Port serving tourism and public traffic. A port serving nautical tourism (on annual, seasonal and/or daily level) is a functional development direction focused primarily on providing the infrastructure and superstructure basis for accommodating nautical vessels and providing additional facilities to boaters, berth users, with the goal of creating a higher level of added value of the port itself, as well as its surroundings, namely, the tourist economy. This development direction refers to accommodation of nautical vessels, with special focus on efficient use of the available capacity in the summer months (tourist season) for provision of services of transit berths (daily and several-day berthing).

Port serving fisheries and industry. A port serving fisheries and industry means satisfying the needs of the local professional fishermen for berths and accompanying port services in the form of providing relevant accommodation and maintenance of fishing boats and transhipment of fish and other seafood. The basic purpose of such a development line is to improve the competitiveness of fisheries and developing new product and processing capacities of fishery and other seafood.

Status quo. The port of Rovinj is a multifunctional port open for public transport with a rich fishing tradition which is still cherished today. Although primarily oriented to municipal berths in the service of citizens, in the summer months Rovinj's harbor is also a lively nautical destination and a frequently visited cruise ship port of call.

\subsection{Analysis of the Stakeholders}

In the model of county and local port development in relation to the spatial concept of the town, several stakeholders may be singled out that can influence the selection and the decision on measures [18]. By analysing the recommended model and the group of stakeholders, the most significant thereof are singled out, as well as their needs [19]:

The need of the local population - regular users of port services is reflected in the continuity of providing port services from the basic port activity with the accompanying infrastructure and superstructure, as well as other economic activities directly linked by economy, traffic or technology to the basic port activities, satisfying all requirements for public utility berthing.

The need of the local population is reflected in the quality of maintaining port infrastructure (quay walls, breakwater, etc.), as well as the promenade, adhering to all conservation studies in order to minimise the changes to the appearance of the town and the needs of private companies - hiring of workforce. 
The need of occasional population is reflected in meeting all the requirements for public utility berths and the quality of maintaining port infrastructure (quay walls, breakwater, etc.).

The need of tourists may be reflected in the quality of disembarking spots i.e. operative pier with the accompanying infrastructure (terminal), additional tourist and economic facilities (restaurants, cafes, ... with terraces on the sea), systematisation of an operative pier near bus stops and/or train stations, taxi services, etc. and systematisation of the operative pier near the city centre.

The need of the shipbuilders and the ship maintenance service providers is reflected in appropriate infrastructure with the pertaining substructure and infrastructure for rendering shipbuilding services and vessel maintenance services, direct connection to the road traffic, vicinity or connection to the town water processing facilities, vicinity of specialised stores for spare parts, paint, tools, etc., need of private companies for hiring workforce, return of financial value of investment in equipment.

The needs of boaters are reflected in availability of nautical berths, systematisation of nautical berths near the centre of the town, equipping the town with maritime petrol station, provision of high-quality port services from the basic port activity with the accompanying infrastructure and superstructure, as well as other economic activities directly linked by economy, traffic or technology to the basic port activities, and quality of berth safety.

The need of the fishermen is reflected in basic port activity with the accompanying infrastructure and superstructure, as well as other infrastructure for unloading fish and loading fuel, ice and fishing equipment, providing area on land for spreading and repair of nets, providing storage for fishing tool, providing ice machines and direct connection to the road traffic system.
The need of passenger and cargo transport may be reflected in the quality of operative pier, equipped by infrastructure (hydrant, water, electricity etc.), systematisation of operative pier near the centre of the town, systematisation of operative pier near the bus stops and/or train stations, taxi service, etc., and systematisation of the point of disembarkment with direct connection and road (and/or rail) traffic system.

\subsection{Defining the Indicators}

An indicator represents a point of view by which certain solutions are evaluated, quantifying satisfaction of the indicators [20]. However, due to the need of a comprehensive research of the issue of forming possible models of county and local ports in relation to the spatial concept of the town, there is a need for an approach which is not restricted to analysing individual types of indicators, but which takes into consideration simultaneous influence of several various indicators when forming possible solutions. In this part, with previously defined stakeholders (interest groups) indicators are connected, i.e. indicators are formed (metrics and variable) which may be used for measuring the values of the criteria for each alternative. The indicators provide a grading scale (e.g. from 0 to 5 or from 1 to 10) used for evaluating the values of the criteria for each alternative from the aspect of an "interest group". Indicators are usually of a quantitative nature, but they may also be prepared as qualitative indicators. The basic principle, based on which indicators have been chosen for the selection of the development model for county and local ports in relation to the special concept of the town, is the result of implemented and analysed survey and a detailed research [21]. Indicators and sub-indicators are listed in Tab. 1.

Table 1 Indicators and sub-indicators

\begin{tabular}{|c|c|c|c|}
\hline INDICATOR MARK & INDICATORS & $\begin{array}{c}\text { SUB-INDICATOR } \\
\text { MARK }\end{array}$ & SUB-INDICATOR \\
\hline \multirow{3}{*}{ DVTUL } & \multirow{3}{*}{$\begin{array}{l}\text { Added value of the port } \\
\text { management body }\end{array}$} & DVTUL1 & Assets from the budget (municipality, town, county, country) \\
\hline & & DVTUL2 & Port dues \\
\hline & & DVTUL3 & Concession fees \\
\hline \multirow{6}{*}{ ZLSKU } & \multirow{6}{*}{$\begin{array}{c}\text { Satisfaction of local } \\
\text { population, regular users } \\
\text { of port services }\end{array}$} & ZLSKU1 & Infrastructure quality and condition \\
\hline & & ZLSKU2 & Quality and condition of mooring devices \\
\hline & & ZLSKU3 & Condition of infrastructure for loading/unloading of passengers and/or cargo \\
\hline & & ZLSKU4 & Level of possibility to access the port area by vehicles \\
\hline & & ZLSKU5 & Level of possibility to meet all requests for public utility berths \\
\hline & & ZLSKU6 & Fire protection level \\
\hline \multirow{4}{*}{ ZLS } & \multirow{4}{*}{$\begin{array}{c}\text { Satisfaction of local } \\
\text { population, non-users of } \\
\text { port services }\end{array}$} & ZLS1 & $\begin{array}{l}\text { Level of evaluating he port area as an urban component within the town } \\
\text { appearance }\end{array}$ \\
\hline & & ZLS2 & Level of environmental protection in the port area \\
\hline & & ZLS3 & Level of quality of public utility equipment on shore \\
\hline & & ZLS4 & Fire protection level \\
\hline \multirow{7}{*}{ ZT } & \multirow{7}{*}{ Satisfaction of tourists } & ZT1 & $\begin{array}{l}\text { Quality of infrastructure and mooring devices for cruisers and ships for } \\
\text { occasional passenger transport }\end{array}$ \\
\hline & & ZT2 & $\begin{array}{l}\text { Quality of offered contents to guests from cruisers or ships for occasional } \\
\text { passenger transport }\end{array}$ \\
\hline & & ZT3 & Distance from the point of disembarkment to the centre of the town \\
\hline & & ZT4 & Distance from the point of disembarkment to the bus stop \\
\hline & & ZT5 & Quality of performing border-crossing formalities \\
\hline & & ZT6 & Quality of the port management body in implementing port safety plan \\
\hline & & ZT7 & Quality of excursions offered by tourist agencies \\
\hline \multirow{6}{*}{$\mathrm{ZN}$} & \multirow{6}{*}{ Satisfaction of boaters } & ZN1 & Quality of mooring devices \\
\hline & & ZN2 & Quality of mooring service \\
\hline & & ZN3 & Quality of vessel maintenance service \\
\hline & & ZN4 & Quality of facilities on shore (toilet, shower, reception) \\
\hline & & ZN5 & Quality of the system of waste disposal from vessels \\
\hline & & ZN6 & Level of possibility to meet all requests for nautical berths \\
\hline
\end{tabular}


Table 1 Indicators and sub-indicators (continuation)

\begin{tabular}{|c|c|c|c|}
\hline INDICATOR MARK & INDICATORS & $\begin{array}{l}\text { SUB-INDICATOR } \\
\text { MARK }\end{array}$ & SUB-INDICATOR \\
\hline \multirow{7}{*}{ ZGS } & \multirow{7}{*}{$\begin{array}{l}\text { Satisfaction of the } \\
\text { economic sector }\end{array}$} & ZGS1 & Quality and condition fishing infrastructure \\
\hline & & ZGS2 & Quality and condition of unloading devices \\
\hline & & ZGS3 & Quality and condition of port infrastructure \\
\hline & & ZGS4 & Quality and condition of mooring devices \\
\hline & & ZGS5 & Quality of the system of waste disposal from vessels \\
\hline & & ZGS6 & Quality of vessel maintenance service \\
\hline & & ZGS7 & Fire protection level \\
\hline \multirow{4}{*}{ ILIO } & \multirow{4}{*}{$\begin{array}{l}\text { Investments into port } \\
\text { infrastructure and } \\
\text { maintenance }\end{array}$} & ILIO1 & Investments in design \\
\hline & & ILIO2 & Investments in restoration and maintenance \\
\hline & & ILIO3 & Investments in construction \\
\hline & & ILIO4 & Investments in implementation of port security \\
\hline ZAP & Employment & ZAP & Workplace change process \\
\hline \multirow{5}{*}{ DVSD } & \multirow{5}{*}{$\begin{array}{l}\text { Added value of secondary } \\
\text { economic activities }\end{array}$} & DVSD1 & $\begin{array}{l}\text { Level of possibility to present indigenous products to the boaters, tourists } \\
\text { from cruisers or ships in occasional transport }\end{array}$ \\
\hline & & DVSD2 & Distance from the point of disembarkment to the centre of the town \\
\hline & & DVSD3 & Level of inquiries for buying local and/or indigenous products \\
\hline & & DVSD4 & Quality of excursions offered by tourist agencies \\
\hline & & DVSD5 & Quality of vessel maintenance service \\
\hline
\end{tabular}

\subsection{Survey Questionnaire}

For the purpose of a comprehensive research of the issue of forming possible scenarios of developing county and local ports in relation to the spatial concept of the town of Rovinj, an approach is necessary, which is not limited to analysing individual types of indicators, but which takes into consideration the influence of several different subindicators when forming possible scenarios (solutions). The survey of experts from various fields of scientific research was conducted for the purpose of defining the importance (weighting factor) of indicators and values of individual sub-indicators for the offered scenarios, which shall be used to analyse possible solutions of developing county and local ports in relation to the spatial concept of the port and the town, using Multi-Actor Multi-Criteria Analysis (MAMCA). The subjects were required to determine the significance (i.e. weight) of the offered subindicators in evaluating the offered scenarios of developing county and local ports in relation to the spatial concept of the port and the town of Rovinj. The subjects evaluated criteria on the scale from 0 to 5 , where 0 was assigned to the criterion they considered unimportant (irrelevant), and 5 to the criterion of exceptional significance for evaluation of the model of developing the county and local ports in relation to the spatial concept of the port and the town [10].

In the survey of inhabitants, tourists, boaters and entrepreneurs, the research was based on gathering primary data in personal interviews with inhabitants, tourists, crew, fishermen, boaters, entrepreneurs, and other stakeholders, and it was performed in the surroundings of port Rovinj. The research included the total of 452 subjects, 68 thereof from the relevant profession or from the public sector, 84 inhabitants using the port services, 43 inhabitants not using the port services, 95 tourists, 79 boaters, 23 fishermen, 29 ship-owners or crew members in occasional and line transport of passengers, and 31 entrepreneurs.

\subsection{Evaluating the survey questionnaire results}

Evaluating the scenarios based on the selected indicators was the basic precondition for applying the multi-criteria decision-making procedure, i.e. multicriteria ranking by means of the PROMETHEE procedure.

\begin{tabular}{|c|c|c|c|c|c|c|c|}
\hline \multicolumn{3}{|c|}{ INDICATORS } & \multicolumn{5}{|c|}{ SCENARIOS } \\
\hline Code & Full name & $\begin{array}{c}\text { Unit of } \\
\text { measurement }\end{array}$ & 1 & 2 & 3 & 4 & 5 \\
\hline DVTUL & $\begin{array}{c}\text { Added value of the port } \\
\text { management body }\end{array}$ & Income / HRK & 4.600 .000 & 4.000 .000 & 5.500 .000 & 3.900 .000 & 4.770 .000 \\
\hline ZLSKU & $\begin{array}{c}\text { Satisfaction of local } \\
\text { population, regular users of } \\
\text { port services }\end{array}$ & $\begin{array}{l}\text { Satisfaction } \\
\text { score }\end{array}$ & 4.23 & 3.30 & 3.39 & 3.19 & 3.16 \\
\hline ZLS & $\begin{array}{c}\text { Satisfaction of local } \\
\text { population, non-users of } \\
\text { port services }\end{array}$ & $\begin{array}{l}\text { Satisfaction } \\
\text { score }\end{array}$ & 3.15 & 3.39 & 2.77 & 3.03 & 3.40 \\
\hline ZT & Satisfaction of tourists & $\begin{array}{l}\text { Satisfaction } \\
\text { score }\end{array}$ & 3.08 & 2.16 & 4.09 & 2.26 & 4.16 \\
\hline $\mathrm{ZN}$ & Satisfaction of boaters & $\begin{array}{l}\text { Satisfaction } \\
\text { score }\end{array}$ & 2.10 & 2.07 & 4.13 & 2.34 & 2.98 \\
\hline ZGS & $\begin{array}{l}\text { Satisfaction of the } \\
\text { economic sector }\end{array}$ & $\begin{array}{l}\text { Satisfaction } \\
\text { score }\end{array}$ & 3.31 & 2.60 & 3.72 & 4.37 & 4.05 \\
\hline ILIO & $\begin{array}{l}\text { Investments into port } \\
\text { infrastructure and } \\
\text { maintenance } \\
\end{array}$ & $\begin{array}{l}\text { Expenditure / } \\
\text { HRK }\end{array}$ & 3.600 .000 & 3.000 .000 & 4.400 .000 & 2.900 .000 & 3.600 .000 \\
\hline ZAP & Employment & Score / \% & 2.12 & 1.25 & 3.96 & 3.19 & 3 \\
\hline DVSD & $\begin{array}{l}\text { Added value of secondary } \\
\text { economic activities }\end{array}$ & $\begin{array}{l}\text { Satisfaction } \\
\text { score }\end{array}$ & 2.65 & 2.62 & 3.67 & 3.05 & 3.53 \\
\hline
\end{tabular}


Depending on the indicator, some evaluation indicators are expressed in a quantitative manner, i.e. by specific data (Added value of the port management body and investment in port infrastructure), while the other criteria were the subject of pondering (evaluation), i.e. the scenarios (suggested models) were evaluated pursuant to individual indicators by subjective, but also by scientifically substantiated marks (Tab. 2).

Following the above said, it should be pointed out that the assigned weighted factors of the indicators refer to the conclusions received by research and that due to a restricted scope of the research not all possible combinations of the weight factor indicators (subindicators) were analysed, but only some of the combinations, although the multi-criteria programming by means of Visual PROMETHEE offers the option of ranking scenarios pursuant to different or all possible combinations of the weighting factor indicators. The Weighting factors are presented in Tab. 3.

Table 3 Determining the weight factor

\begin{tabular}{|c|c|c|c|c|c|}
\hline & MIN & MAX & AVERAGE & STDEV & $\begin{array}{c}\text { WEIGHTING } \\
\text { FACTOR }\end{array}$ \\
\hline Added value of the port management body & 6 & 10 & 8.8529 & 0.9185 & $14.98 \%$ \\
\hline Satisfaction of local population, regular users of port services & 7 & 10 & 9.3824 & 0.6917 & $15.88 \%$ \\
\hline Satisfaction of local population, non-users of port services & 1 & 8 & 4.0294 & 1.3710 & $6.82 \%$ \\
\hline Satisfaction of tourists & 3 & 8 & 5.3824 & 1.4663 & $9.11 \%$ \\
\hline Satisfaction of boaters & 3 & 8 & 5.3824 & 1.4663 & $9.11 \%$ \\
\hline Satisfaction of the economic sector & 4 & 9 & 5.8235 & 1.2331 & $9.86 \%$ \\
\hline Investments into port infrastructure and maintenance & 5 & 9 & 7.8235 & 0.9295 & $13.24 \%$ \\
\hline Employment & 3 & 9 & 7.0882 & 1.4220 & $12.00 \%$ \\
\hline Added value of secondary economic activities & 3 & 8 & 5.3235 & 1.4189 & $9.01 \%$ \\
\hline
\end{tabular}

The analysis of Tab. 3 shows that the most important indicators are: Satisfaction of the local population, users of port services $(15.88 \%)$, Added value of the port management body (14.98\%), Investments into port infrastructure and maintenance (13.24\%) and Employment $(12.00 \%)$. The least significant indicators are Satisfaction of the local population, non-users of port services (6.82\%) and Added value of secondary economic activities $(9.01 \%)$.

\section{APPLICATION OF MULTI-CRITERIA ANALYSIS AND PREPARING THE MODELS}

One of the preconditions for applying the multi-criteria decision-making procedure is determining the combinations of selected indicators and the weighting factor indicator, the changing thereof may notice the difference to determining the development model (scenario) [22].

\begin{tabular}{|c|c|c|c|c|c|c|c|c|c|c|c|}
\hline & \multicolumn{2}{|l|}{ Model } & DVTUL & ZLSKU & ZLS & ZT & $\mathrm{ZN}$ & ZGS & INIO & ZAP & DVSD \\
\hline & \multicolumn{2}{|l|}{ Unit } & value & vote & vote & vote & vote & vote & value & vote & vote \\
\hline & \multicolumn{2}{|l|}{ Cluster/Group } & & & & & & & & & \\
\hline & \multicolumn{2}{|l|}{ Preferences } & & & & & & & & & \\
\hline & \multicolumn{2}{|l|}{ Min/Max } & $\max$ & $\max$ & $\max$ & $\max$ & $\max$ & $\max$ & $\max$ & $\max$ & $\max$ \\
\hline & \multicolumn{2}{|l|}{ Weight } & 14,98 & 15,88 & 6,82 & 9,11 & 9,11 & 9,86 & 13,24 & 12,00 & 9,01 \\
\hline & \multicolumn{2}{|l|}{ Preference Fn. } & Usual & Usual & Usual & Usual & Usual & Usual & Usual & Usual & Usual \\
\hline & \multicolumn{2}{|l|}{ Thresholds } & absolute & absolute & absolute & absolute & absolute & absolute & absolute & absolute & absolute \\
\hline & \multicolumn{2}{|l|}{-Q: Indifference } & $\mathrm{n} / \mathrm{a}$ & $\mathrm{n} / \mathrm{a}$ & $\mathrm{n} / \mathrm{a}$ & $\mathrm{n} / \mathrm{a}$ & $\mathrm{n} / \mathrm{a}$ & $\mathrm{n} / \mathrm{a}$ & $n / a$ & n/a & $\mathrm{n} / \mathrm{a}$ \\
\hline & \multicolumn{2}{|l|}{-P: Preference } & $\mathrm{n} / \mathrm{a}$ & $n / a$ & $n / a$ & $n / a$ & $\mathrm{n} / \mathrm{a}$ & $\mathrm{n} / \mathrm{a}$ & $n / a$ & $\mathrm{n} / \mathrm{a}$ & $\mathrm{n} / \mathrm{a}$ \\
\hline & \multicolumn{2}{|l|}{-S: Gaussian } & $\mathrm{n} / \mathrm{a}$ & $n / a$ & $\mathrm{n} / \mathrm{a}$ & $n / a$ & $\mathrm{n} / \mathrm{a}$ & $\mathrm{n} / \mathrm{a}$ & $\mathrm{n} / \mathrm{a}$ & $\mathrm{n} / \mathrm{a}$ & $\mathrm{n} / \mathrm{a}$ \\
\hline & \multicolumn{2}{|l|}{ Statistics } & & & & & & & & & \\
\hline & \multicolumn{2}{|l|}{ Minimum } & $3.900 .000,00$ & 3,16 & 2,77 & 2,16 & 2,07 & 2,60 & $2.900 .000,00$ & 1,25 & 2,62 \\
\hline & \multicolumn{2}{|l|}{ Maximum } & $5.500 .000,00$ & 4,23 & 3,40 & 4,16 & 4,13 & 4,37 & $4.400 .000,00$ & 3,96 & 3,67 \\
\hline & \multicolumn{2}{|l|}{ Average } & $4.554 .000,00$ & 3,45 & 3,15 & 3,15 & 2,72 & 3,61 & $3.500 .000,00$ & 2,70 & 3,10 \\
\hline & \multicolumn{2}{|l|}{ Standard Dev. } & $579.365,17 \mathrm{kn}$ & 0,40 & 0,24 & 0,86 & 0,78 & 0,62 & $536.656,31 \mathrm{kn}$ & 0,93 & 0,43 \\
\hline & \multicolumn{2}{|l|}{ Evaluations } & & & & & & & & & \\
\hline$\square$ & Scenario 1 & $\square$ & $4.600 .000,00$ & 4,23 & 3,15 & 3,08 & 2,10 & 3,31 & $3.600 .000,00$ & 2,12 & 2,65 \\
\hline$\square$ & Scenario 2 & $\square$ & $4.000 .000,00$ & 3,30 & 3,39 & 2,16 & 2,07 & 2,60 & $3.000 .000,00$ & 1,25 & 2,62 \\
\hline$\square$ & Scenario 3 & $\square$ & $5.500 .000,00$ & 3,39 & 2,77 & 4,09 & 4,13 & 3,72 & $4,400.000,00$ & 3,96 & 3,67 \\
\hline$\square$ & Scenario 4 & $\square$ & $3.900 .000,00$ & 3,19 & 3,03 & 2,26 & 2,34 & 4,37 & $2.900 .000,00$ & 3,19 & 3,05 \\
\hline$\square$ & Scenario 5 & $\square$ & $4.770 .000,00$ & 3,16 & 3,40 & 4,16 & 2,98 & 4,05 & $3.600 .000,00$ & 3,00 & 3,53 \\
\hline
\end{tabular}

\subsection{Ranking Individual Scenarios per Indicators - PROMETHEE}

The entire procedure of multi-criteria decision-making is based on the procedure called PROMETHEE II, i.e. the procedure of complete scenario (type) ranking where a certain rank belongs to each scenario. By contrast, when applying the PROMETHEE I procedure, referring partly to ranking scenarios, there is an option that several different scenarios are equally favourable, i.e. that they are ranked 
identically [2]. After defining all the elements of the model: goal, evaluation indicators, possible scenarios of developing county and local ports in relation to the complementarity of the spatial concept of the port and the town of Rovinj, the methodology of multi-criterial analysis must be defined by the software solution. For the needs of resolving the research problem, the data in the following manner [16]:

1. Creating the hierarchy of the problem-solving process where the position is defined within the hierarchy, as well as interactions.

2. Determining all possible relations by calculating parity between individual relations, namely, between the example of the local port (town of Rovinj) and the indicators, the example of the local port (town of Rovinj) and possible scenarios and possible indicators and defined scenarios.

3. Selecting the best development scenario.

The next step of the procedure is to resolve complex parity matrices i.e. calculation of all relations and weights from the data analysis from the survey questionnaire and the data from the Operation report plan and the Financial report of the Rovinj Port Authority. After the entered input data (Fig. 1), the results of the computer program indicate ranking of scenarios, depending on the given influences of the indicators. Ranking the scenarios enables bringing conclusions in compliance with the county and local ports development model in relation to the complementarity of the spatial concept of the port and the town of Rovinj, and the purpose and the goal of the research, as well as with the main hypothesis.

Tab. 4 shows a review of the output data i.e. the results of the implemented procedure of multi-criteria ranking of implementation scenarios of the county and local ports development model in relation to the complementarity of the spatial concept of the port and the town of Rovinj. The results refer to ranking of individual scenarios in relation to the defined indicators.

Table 4 Review of ranking individual scenarios per indicators

\begin{tabular}{|c|c|c|c|c|c|c|}
\hline \multirow{2}{*}{ No. } & \multirow{2}{*}{ INDICATORS } & \multicolumn{5}{|c|}{ SCENARIOS } \\
\hline & & 1 & 2 & 3 & 4 & 5 \\
\hline 1. & Added value of the port management body & 3 & 4 & 1 & 5 & 2 \\
\hline 2. & Satisfaction of local population, regular users of port services & 1 & 3 & 2 & 4 & 5 \\
\hline 3. & Satisfaction of local population, non-users of port services & 3 & 2 & 5 & 4 & 1 \\
\hline 4. & Satisfaction of tourists & 3 & 5 & 2 & 4 & 1 \\
\hline 5. & Satisfaction of boaters & 4 & 5 & 1 & 3 & 2 \\
\hline 6. & Satisfaction of the economic sector & 4 & 5 & 3 & 1 & 2 \\
\hline 7. & Investments into port infrastructure and maintenance & 2 & 4 & 1 & 5 & 3 \\
\hline 8. & Employment & 4 & 5 & 1 & 2 & 3 \\
\hline 9. & Added value of secondary economic activities & 4 & 5 & 1 & 3 & 2 \\
\hline & TOTAL $(1+2+3+4+5+6+7+8+9) / 9:$ & 3.11 & 4.22 & 1.88 & 3.44 & 2.33 \\
\hline & LEVEL: & 3 & 5 & 1 & 4 & 2 \\
\hline
\end{tabular}

\subsection{Analysing Profiles of Individual Scenarios per Indicators}

Tab. 5 compares profiles of 5 scenarios per indicators. The results of the scores are between +1 (the highest score) and -1 (the lowest score). The above said results in obtaining the estimates of advantages and disadvantages of each indicator for individual scenario.

By using a computer program, and by comparing the graded indicators of all scenarios (Tab. 5), it can be concluded that the indicator of added value of the port management body from scenario 3 scored +1 , which means that it is more competitive than scenario 5 which scored +0.5 , while other scenarios have a negative trend. The said procedure may be used to analyse and compare all other indicators as well. After inputting the data and analysing the results of the computer program, it is concluded that the best scenarios for the port of the town of Rovinj are Scenario 3 - Port serving tourism and public coastal occasional and line transport of passengers, and Scenario 5 - Port Status quo. The most acceptable scenario for the port of Rovinj is the one profiling Rovinj as a port for nautical tourism and international line and coastal traffic.

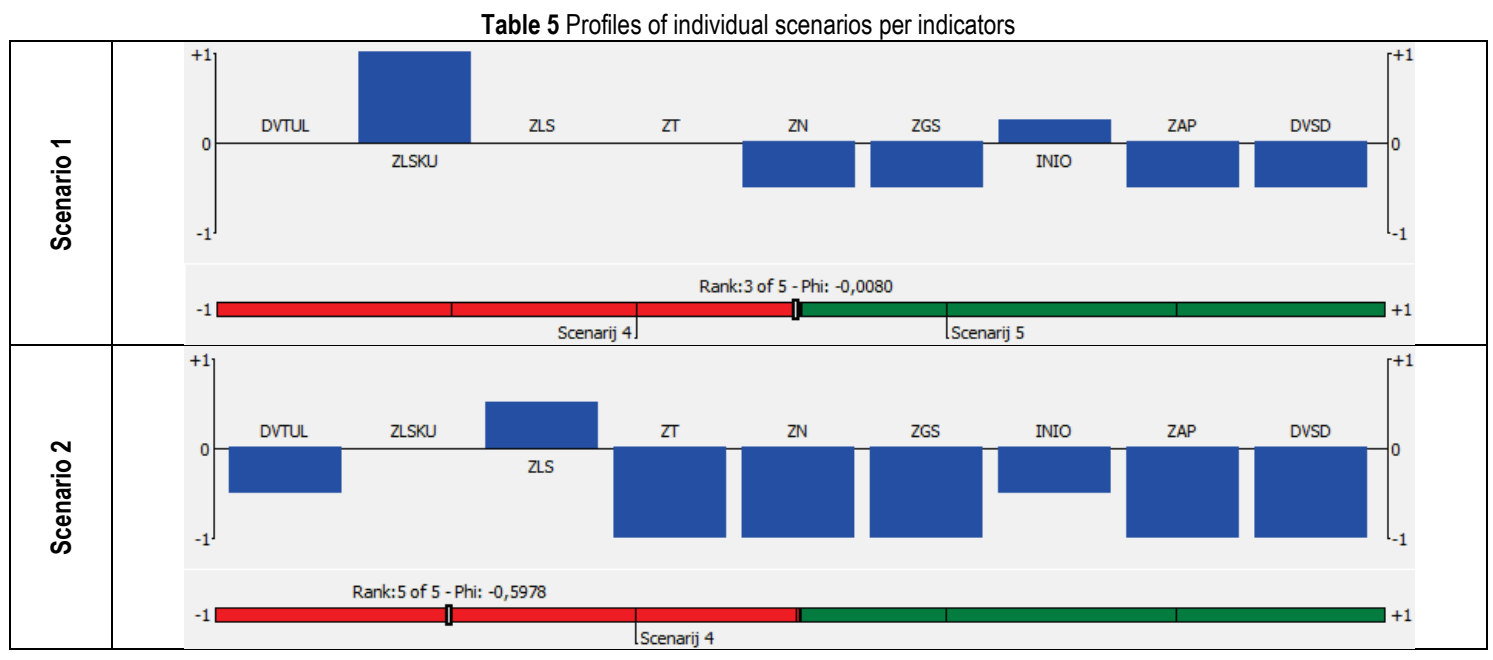




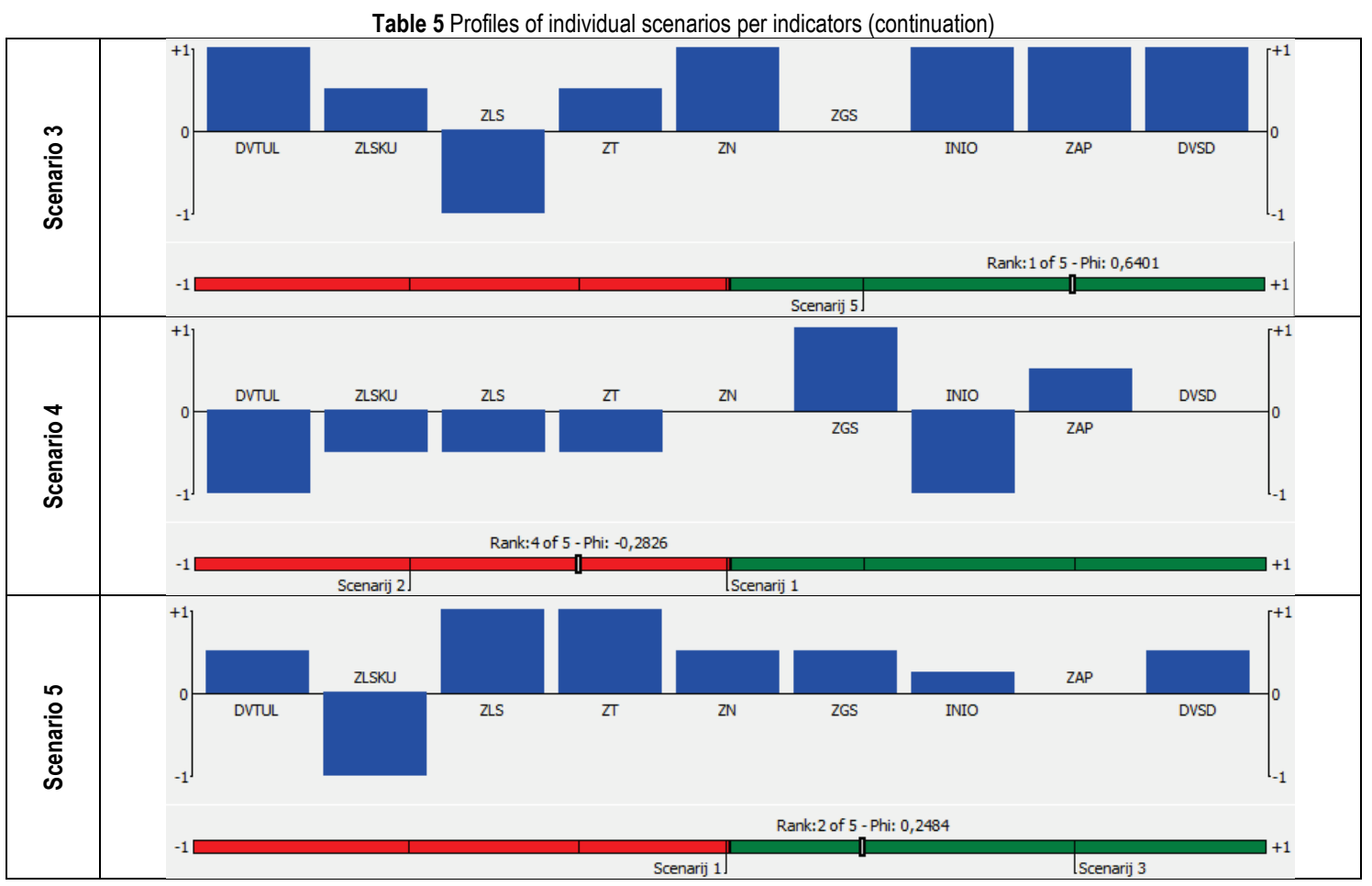

\section{TESTING THE MODEL BY IMPLEMENTING URBAN MEASURES FOR COUNTY AND LOCAL PORT DEVELOPMENT AS A CONSTITUENT PART OF THE CONCEPT OF THE TOWN}

Urban planning measures are decisions brought by the local authority via spatial plans, with the goal of permanent improvement of economic, environmental, climatic, social and demographic conditions of the urban area. Urban planning measures are implemented by the urban strategy of the time, determined by a range of factors, one of the most important factor being its location, mostly in the centre of the town. The authority managing the port wishes to obtain new areas for its activities, either to the detriment of the town or the sea, while towns are interested in taking over the port areas to develop various cultural, recreational, tourist and other activities.

Urban measures are those that, via comparative analyses, indicate possible types of developing county and local ports in relation to the spatial concept of the town where there are different types, such as: 1) Expanding the port area, 2) Decrease of the port area, 3) Forming remote port areas, 4) Transfer of the port area outside the centre of the town, 5) Increasing the number of public utility berths/decreasing the number of business berths/same number of nautical berths, 6) Increasing the number of public utility berths/decreasing the number of nautical berths/same number of business berths, 7) Increasing the number of business berths/decreasing the number of public utility berths/same number of nautical berths, 8) Increasing the number of business berths/decreasing the number of nautical berths/same number of public utility berths, 9) Increasing the number of nautical berths/decreasing the number of business berths/same number of public utility berths and 10) Increasing the number of nautical berths/decreasing the number of public utility berths/same number of business berths.
A computer program enables comparison of preferences of individual scenarios concerning the influence of each indicator. Ranking individual implementation scenarios through the county and local ports development model in relation to the complementarity of spatial concept of the port and the town of Rovinj, including various indicator combinations, is presented below. The computer program assigns an indifference index $(P h i)$ to each scenario. Based on the preference index, the so-called positive output $\left(P h i^{+}\right)$and negative input $\left(P h i^{-}\right)$flows are determined, presenting the sum of relevant multi-criteria preference indices. The higher the positive flow, the more dominant the scenario in relation to other scenarios. Based on the positive and negative flow, the scenarios are ranked in the manner that the so called net flow is calculated pursuant to the expression: $\operatorname{Phi}(a)=P h i^{+}(a)-P h i^{-}(a)$. The scenario with higher net flow has higher rank (Fig. 2).

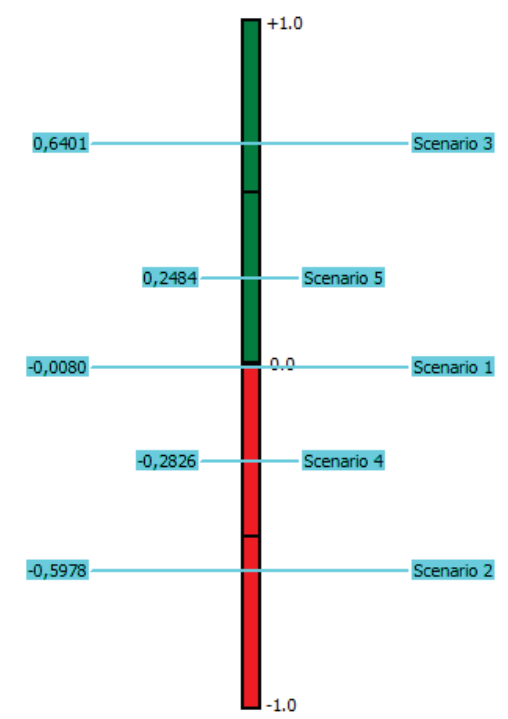

Figure 2 Order of scenarios and net flows based on the results of multi-criteria 


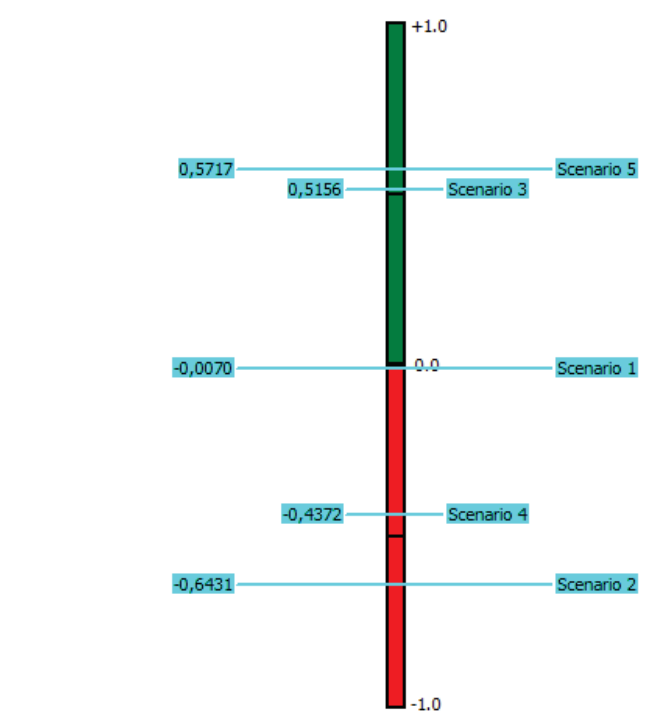

Figure 3 Order of the scenarios and net flows pursuant to the results of multicriteria analysis after implementing the urban measure of Expanding the port area in Scenario 5

For the needs of the town of Rovinj, by analysing the surveyed inhabitants that use port services, the spatial planners and individuals designing development of county and local ports, and port management bodies, it was concluded that the best solution for the future development of county and local ports is to implement the urban development method of expanding the port area or to transfer the same outside the centre of the town, and it is also necessary to build a new, small public utility port, which would then result in the increase of the number of public utility berths, therefore, meeting the needs of the inhabitants.

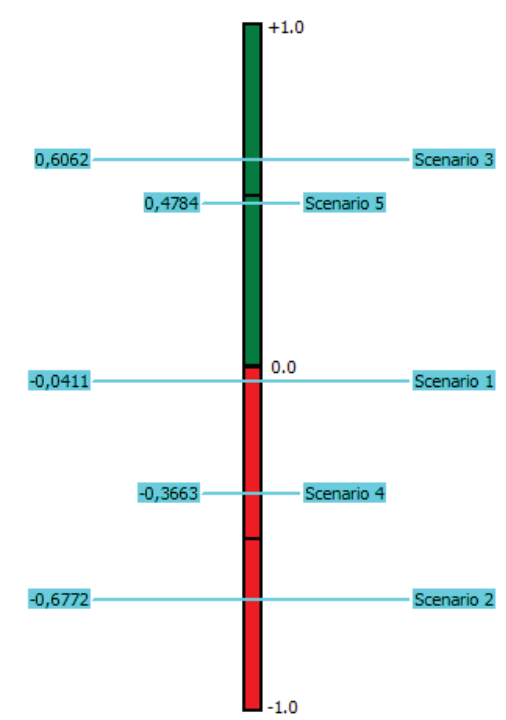

Figure 4 Order of the scenarios and net flows pursuant to the results of multicriteria analysis after implementing the urban measure of Forming remote port areas in Scenario 5.

In order to test the suggested model, a simulation of the implementation of urban planning measures shall be performed in this chapter. By expanding the port area and/or forming remote port areas in the manner to modify parameters in Scenario 5, in compliance with the flow of the measure defined in each urban measure, the same shall become the most acceptable one for the port of the town of Rovinj. Figs. 3 and 4 show the new order of scenarios after the correction of parameters was performed in Scenario 5 in compliance with the flow of the measures from the urban planning measures: Expanding the port area and Forming remote port areas.

If the same are displayed and compared to the values of Scenario 5 in the main model, it can be determined that by implementing the urban planning measure of Expanding the port area, the situation is significantly different and Scenario 5, in compliance with the newly calculated index, shifts to the first place, while the same cannot be determined if applying the urban planning measure of Forming remote port areas, which is displayed in Fig. 5.

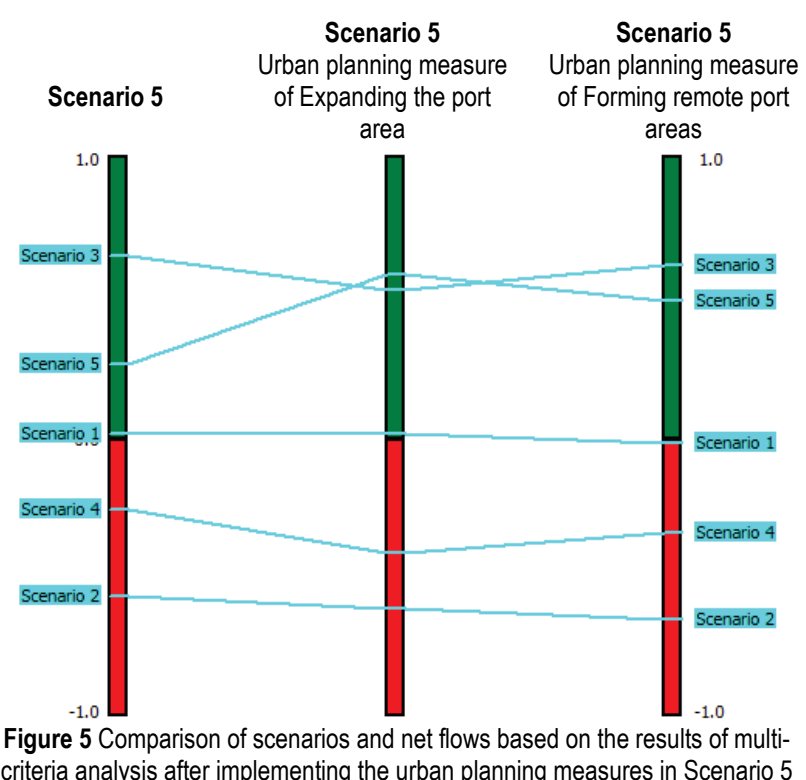

By analysing Scenario 5 before and after implementation of urban measures, and by comparing the indicators (Tab. 6), it can be determined that the indicator Satisfaction of the local inhabitants, users of port services that at the beginning had the value of -1 , after the implementation of urban plan methods increased to +0.5 , while in implementation of the urban planning method Expanding the port area there is also the increase of the indicators Employment and Added value of secondary economic activities. The only decrease of the index value is visible in Satisfaction of the inhabitants, non-users of port services.

By analysing the results, it can be determined that by applying the offered urban planning measures it is possible to change the flow of the desired scenario and/or just the value of individual indicators, in order to eventually have the best ranking of individual scenarios. Following the above said, it can be concluded that the offered model of developing county and local ports in relation to the spatial concept of the town meets the expectations, i.e. that it is applicable. 
Table 6 Profiles of Scenario 5 pursuant to indicators

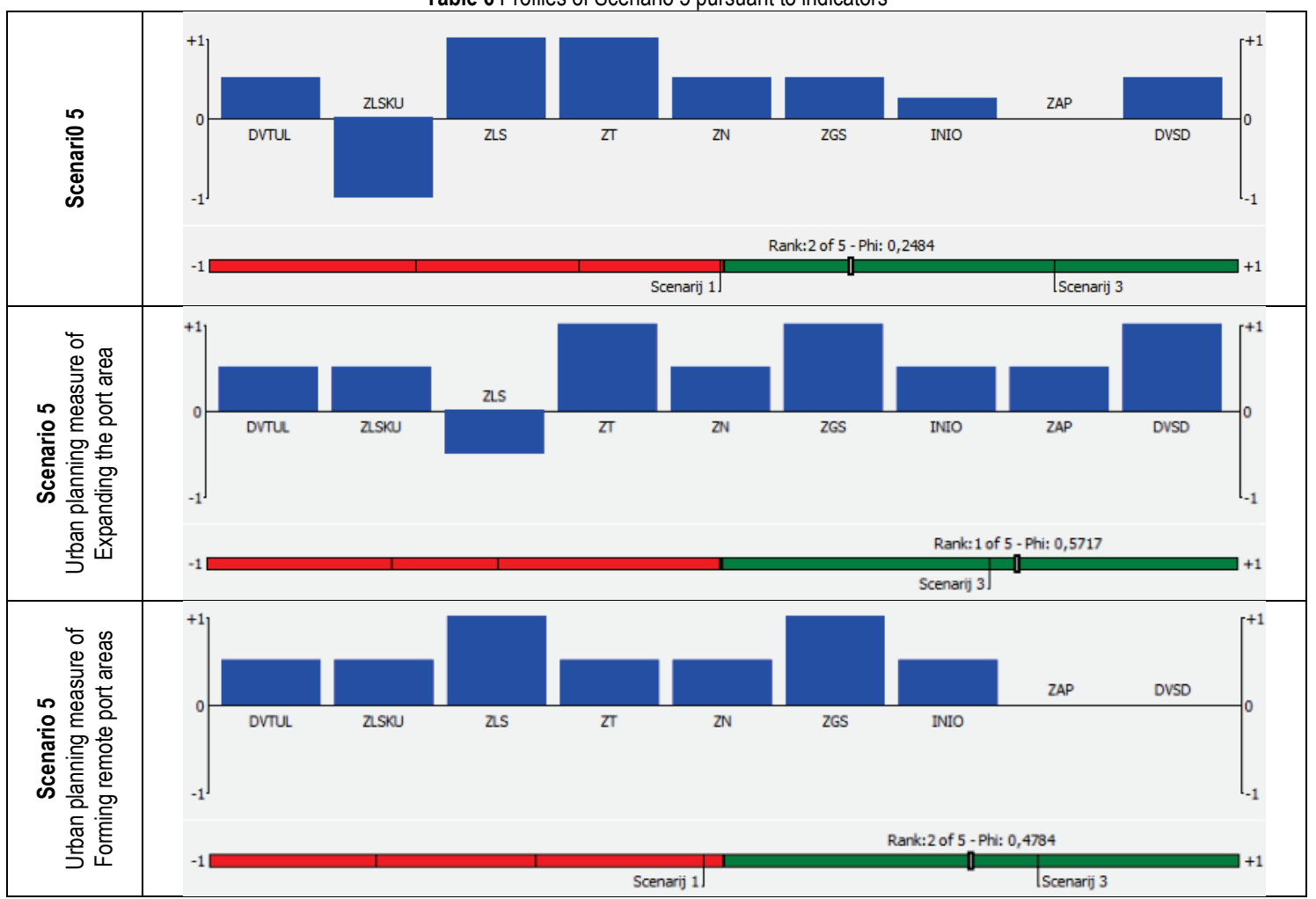

\section{CONCLUSION}

The said problems are visible in the Republic of Croatia where all relevant factors influencing the development of the town and the port as a joint system are virtually not taken into consideration at all. As a result, the problems that ports and towns face are often considered separately. The most significant problem in development of ports with county and local relevance is that development plans brought by port authorities as port and port area management bodies usually have no coverage in spatial-planning solutions of towns and counties.

The reverse happens as well, when port authorities along with the town and/or county plan solutions are acquainted only via the opinion of the relevant administrative body in charge of implementation of the spatial development document, and by then it is too late to make any significant changes or interventions. The above said indicates that not all subjects were active participants in the planning procedure for ports and the pertaining port areas in the documents of physical planning. The result of such a situation are port areas that are not based on the development plans made by the port management authorities, which are usually unsatisfactory either by the structure of represented port activities, or by the capacity, and especially by the surface area and the shape of the port area.

The results of the research indicate that it is necessary to simplify the decision-making process and the procedure of bringing spatial plans for county and local ports development by shortening the spatial and temporal gaps, by removing idle running and returns, by higher level of specialisation, by compliance with legal definitions of effective use of information and by more ample use of science and knowledge, in order to enable successful and rational county or local port development in relation to the complementarity of spatial concept of the town.

The paper proves that it is necessary to define the role and interconnection of all stakeholders, possible models of port development and indicators and activities, i.e. urban planning measures. By implementing the above said measures and activities, a more effective development of county and local ports shall be enabled in relation to the complementarity of the spatial concept of the town and satisfaction of all stakeholders. The selection of the model (scenario) of developing county and local ports is one of the basic starting points of successful functioning and development of the town and the port. The obtained results of the multi-criteria decision-making indicate that the best solutions for the development of the county and local ports on the example of the Town of Rovinj arise from the models (scenarios) of the Port serving the tourism and public coastal occasional and line transport (Phi 0.6401), while the existing status of the port area of the town of Rovinj is ranked second, the Port Status quo (Phi 0.2484).

The results of the research and the implemented multicriteria decision-making indicate the universality of the model, i.e. confirming the fact that by implementing various urban planning measures the values of the scores of the indicators for each model change as well. The same was proven by implementing urban development model of Expanding the port area where, after the implementation, the Port Status quo scenario reached the first place in the scenario ranking.

\section{REFERENCES}

[1] Jugović, A. (2007). Međuveza grada i pomorsko putničke luke u RH - osnovni čimbenik njihovog uspješnog razvoja, Sveučilište u Rijeci, Pomorski fakultet u Rijeci, 
[2] Pavia, R. \& Di Venosa, M. (2012). Waterfront: from confllict to integration. Trento: ListLab.

[3] Kortit, K., Macharis, C., \& Nijkamp, P. (2003). A Multiactor Multi-criteria analysis of the performance of global cities, Tinbergen Institute, Amsterdam, Discussion Paper.

[4] Malone P. (1996). City, Capital and Water. Psychology Press.

[5] Meyer, H. (1999). City and Port: Urban Planning as a Cultural Venture in London, Barcelona, New York, and Rotterdam: Changing Relations between Public Urban Space and Large-Scale Infrastructure, Utrecht, Netherlands: International Books.

[6] White, K. N., Bellinger, E. G., Saul, A. J., Symes, M., Hendry, K., et al. (1993). Urban Waterside Regeneration: Problems and Prospects. New York and London: Ellis Horwood

[7] Fainstein, S. S. (1994). The City Builders: Property, Politics and Planning in London and New York. Oxford, England, and Cambridge, Mass.: Blackwell

[8] Joerin, F., Theriault, M., \& Musy, A. (2001). Using GIS and outranking multicriteria analysis for land-use suitability assessment. IJGIS - International Journal of Geographical Information Science, 15(2), 153-174. https://doi.org/10.1080/13658810051030487

[9] Kovačić, M. (2010). Selecting the location of a nautical tourism port by applying PROMETHEE and GAIA methods case study - Croatian northern Adriatic. Promet - Traffic \& Transportation

[10] Hadžić, A. P., Jugović, A., \& Host, A. (2014). Evaluation of Development Partnership Scenarios of the Port of Rijeka Using Multi-Actor Multi-Criteria Analysis. Contemporary Local Economic Development Issues.

[11] Macharis, C., Kin, B., Balm, S., \& Ploos van Amstel, W. (2015). Multi-actor participatory decision-making in urban construction logistics. Amsterdam University of Applied Sciences, Amsterdam. https://doi.org/10.3141/2547-12

[12] Kortit, K., Macharis, C., \& Nijkamp, P. (2013). A Multiactor Multi-criteria analysis of the performance of global cities. Tinbergen Institute, Amsterdam, Discussion Paper TI 108/VIII. https://doi.org/10.2139/ssrn.2305943

[13] Kovačić, M. (2010). Selecting the location of a nautical tourism port by applying PROMETHEE and GAIA methods case study - Croatian northern Adriatic. Promet - Traffic \& Transportation, 5(22). https://doi.org/10.7307/ptt.v22i5.199

[14] Mrvica, A., Jugović, A. \& Kovačić, M. (2015). The role and applicability of multi-criteria procedures in the function of defining the model for connecting the mainland and islands and islands in between. Pomorstvo, 29(2.)

[15] Turcksin, L. \& Bernardini, A. (2011). A combined AHPPROMETHEE approach for selecting the most appropriate policy scenario to stimulate a clean ... Vrije Universiteit Brussel, Brussel, Procedia - Social and Behavioral Sciences 20. https://doi.org/10.1016/j.sbspro.2011.08.104

[16] Macharis, C., Turcksin, L., \& Lebeau, K. (2012). Multi actor multi criteria analysis (MAMCA) as a tool to support sustainable decisions: State of use. Vrije Universiteit, Brussel, Decision Support Systems 54, 610-620. https://doi.org/10.1016/j.dss.2012.08.008

[17] Đelović, D. \& Medenica, D. (2008). Izbor modela upravljanja lukom. Naše more, 55(3-4).

[18] Schiozzi, D., Jugović, A., \& Smojver, Ž. (2018). Comparative Analysis of the Related Interests of Relevant Stakeholders in the Development of Seaports in Relation to the Spatial Concept of the City. Pomorstvo, 32(1), 36-41. https://doi.org/10.31217/p.32.1.17

[19] Master plan razvoja luka otvorenih za javni promet županijskog i lokalnog značaja na području Primorskogoranske županije (2016), Sveučilište u Rijeci, Pomorski fakultet
[20] Gaur, P. (2005). Port planning as a strategic tool: a typology. Institute of Transport and Maritime Management Antwerp, University of Antwerp, Antwerpen

[21] Faludi, A. (2010). The performance of spatial planning. Planning Practice \& Research, 15(4). https://doi.org/10.1080/713691907

[22] Jugović, A., Cukrov, M. \& Poletan Jugović, T. (2017). Multi-criteria Optimization of Motorways of the Sea in the Function of the Environment Protection: Case Study of Croatia. Promet - Traffic \& Transportation, 29(4), 463-468. https://doi.org/10.7307/ptt.v29i4.2416

\section{Contact information:}

Mladen JARDAS, mag. ing. logist., assistant (Corresponding author) Faculty of Maritime Studies, University of Rijeka, 51000, Rijeka, Croatia mjardas@pfri.hr

Donald SCHIOZZI, PhD

Rovinj Port Authority

52210, Rovinj, Croatia

donald@port-rovinj.hr

\section{Željko SMOJVER, PhD}

Rijeka Plus Ltd.

51000, Rijeka, Croatia

zeljko.smojver@rijeka-plus.hr 